\title{
Hubungan Shear Wave Elastography Ginjal dengan Estimated Glomerular Filtration Rate pada Pasien Penyakit Ginjal Kronik
}

\section{The Correlation Between Renal Shear Wave Elastography with Estimated Glomerular Filtration Rate in Chronic Kidney Disease}

\author{
Asnita Arif ${ }^{1}$, Nurlaily Idris ${ }^{1}$, Bachtiar Murtala ${ }^{1}$, Andi Alfian $Z^{2}$, Sri Asriyani ${ }^{1}$, Hasyim Kasim ${ }^{3}$ \\ ${ }^{1}$ Departemen Radiologi Fakultas Kedokteran Universitas Hasanuddin Makassar \\ ${ }^{2}$ Departemen IImu Kesehatan Masyarakat/IImu Kedokteran Keluarga Fakultas Kedokteran Universitas Hasanuddin \\ Makassar \\ ${ }^{3}$ Departemen Ilmu Penyakit Dalam Fakultas Kedokteran Universitas Hasanuddin Makassar
}

\begin{abstract}
ABSTRAK
Penyakit ginjal kronik (PGK) merupakan masalah kesehatan global dengan biaya ekonomi tinggi pada sistem kesehatan sehingga dibutuhkan modalitas pencitraan klinis non invasif untuk mendeteksi penyakit ginjal pada stadium awal. Shear wave elastography (SWE) merupakan pemeriksaan imaging untuk menilai tingkat keparahan dari perubahan morfologi kronik ginjal berdasarkan pengukuran elastisitas kortex. Penelitian ini bertujuan mengetahui hubungan antara SWE dengan estimated glomerular filtration rate (eGFR) sehingga SWE dapat direkomendasikan untuk deteksi dini tingkat keparahan penyakit ginjal kronik. Penelitian ini dilakukan di bagian Radiologi Rumah Sakit Umum Pusat Dr. Wahidin Sudirohusodo Makassar dari bulan September 2018 sampai dengan Februari 2019. Desain penelitian yang digunakan adalah observasional dengan rancangan potong lintang. Sampel penelitian sebanyak 118 sampel yang terdiri dari 71 sampel dengan penyakit ginjal kronik dan 47 sampel normal. Pemeriksaan ultrasonografi yang dilakukan dengan metode SWE untuk mengukur shear wave velocity (SWV) pada kedua ginjal dengan tiga kali pengukuran pada kortex ginjal. Nilai median dari SWV pada kedua ginjal dihubungkan dengan eGFR. Data dianalisis dengan uji korelasi Spearman. Hasil penelitian menunjukkan bahwa nilai median SWV pada kelompok sampel normal adalah $2,02 \pm 0,32 \mathrm{~m} / \mathrm{s}$ pada ginjal kanan $2,01 \pm 0,32 \mathrm{~m} / \mathrm{s}$ pada ginjal kiri yang cenderung menurun dengan bertambahnya usia. Terdapat korelasi positif yang signifikan antara nilai SWV pada ginjal kanan dan kiri dengan eGFR, dengan arah korelasi positif $(p<0,0001)$. Pada penelitian ini, terdapat pula korelasi negatif yang signifikan antara tekanan darah dan proteinuria dengan eGFR maupun dengan SWV pada pasien penyakit ginjal kronik.
\end{abstract}

Kata Kunci: Estimated glomerular filtration rate, penyakit ginjal kronik, shear wave velocity ginjal

\begin{abstract}
ABSTRAK
Chronic kidney disease (CKD) is a global health problem with high economic costs in the health system so it requires a noninvasive clinical imaging modality to detect kidney disease at the early stage. Shear wave elastography (SWE) is a simple imaging examination to assess the severity of changes in chronic renal morphology based on measurements of cortex elasticity. This study aimed to assess the relationship of renal shear wave elastography with the estimated glomerular filtration rate (eGFR), so SWE can be recommended for early detection of severe chronic kidney disease. This study was an observational study with a cross-sectional study conducted at the Radiology Departement of the Central General Hospital Dr Wahidin Sudirohusodo Makassar from September 2018 to February 2019. The study sample was 118 samples consisting of 71 samples with chronic kidney disease and 47 normal samples. Data were analyzed by statistical analysis with the Spearman correlation test. The results showed that the median shear wave velocity value in the normal sample group was $2.02 \pm 0.32 \mathrm{~m} / \mathrm{s}$ in the right kidney and $2.01 \pm 0.32 \mathrm{~m} / \mathrm{s}$ in the left kidney, which tended to decrease with age. The results showed a significant correlation between the shear wave velocity values in the right and left kidneys with the estimated glomerular filtration rate, with a positive correlation direction $(p<0,0001)$. In this study, there was also a significant negative correlation between blood pressure and proteinuria with the estimated glomerular filtration rate and with shear wave velocity in patients with chronic kidney disease.
\end{abstract}

Keywords: Chronic kidney disease, estimated glomerular filtration rate, renal shear wave velocity

Korespondensi: Asnita Arif. Departemen Radiologi Fakultas Kedokteran Universitas Hasanuddin Makassar, Jl. Perintis Kemerdekaan KM 11 Makassar90245 Tel.085330775798Email: itafkuh03@gmail.com

DOI: http://dx.doi.org/10.21776/ub.jkb.2019.030.04.10 


\section{PENDAHULUAN}

Profil penyakit di dunia telah berubah dan penyakit kronik sekarang telah mendominasi morbiditas dan mortalitas global dibandingkan penyakit infeksi. Salah satu penyakit kronik tersebut adalah penyakit ginjal kronik (PGK) yang merupakan masalah kesehatan global dengan biaya ekonomi yang tinggi pada sistem kesehatan (1). Penyakit ginjal kronik telah terdiagnosis pada sekitar $10 \%$ populasi dewasa di dunia (2). Diabetes melitus, hipertensi, penyakit vaskuler dan glomerulonefritis telah diketahui sebagai penyebab penyakit ginjal kronik. Adapun penyebab utama terjadinya penyakit ginjal tahap akhir adalah diabetes dan hipertensi (3). Meskipun PGK mengenai semua kelompok usia dan jenis kelamin, namun lebih sering mengenai populasi usia tua. Diperkirakan bahwa prevalensi sekitar 23-36\%, PGK terjadi pada usia $\geq 64$ tahun (2).Terdapat sekitar 19 juta orang dewasa di Amerika serikat mengalami tahap awal PGK dan sekitar 640.000 orang dewasa dengan penyakit ginjal tahap akhir. Diperkirakan jumlah pasien yang akan membutuhkan dialisis atau transplantasi gagal ginjal akan meningkat sekitar 2 juta orang pada tahun 2030 di Amerika Serikat (3). Di Indonesia, insidens pasien penyakit ginjal tahap akhir yang menjalani dialisis pada tahun 2006 sekitar 30,7 juta populasi (4).

Keparahan stadium PGK berkaitan dengan peningkatan morbiditas dan mortalitas. Oleh karena itu, penting untuk menilai tingkat keparahan PGK. Sekarang ini, stadium PGK ditentukan berdasarkan estimated glomerular filtration rate (eGFR), yang merupakan penentuan fungsi ginjal dengan mengukur volume filtrasi yang dibentuk tiap menit melalui kombinasi aktivitas dua juta glomeruli pada kortex ginjal (5). Estimated glomerular filtration rate (eGFR) ini berasal dari nilai kreatinin serum ditentukan dengan berbagai rumus, namun memiliki keterbatasan karena dipengaruhi oleh faktor ras, jenis kelamin dan massa otot $(5,6)$. Adapun rumus eGFR Modification of Diet in Renal Disease (MDRD) dalam satuan $(\mathrm{mL} / \mathrm{menit} / 1,73 \mathrm{~m} 2)=175 \times[$ kreatinin $\operatorname{serum}(\mathrm{SI}) \mathrm{x}$ 0,011312]-1,154x[umur]-0,203x[1,212 untuk kulit hitam $] \times[0,742$ pada perempuan] (7).

Fibrosis intrarenal merupakan jalur akhir untuk semua PGK, dengan derajat fibrosis yang berkaitan dengan tingkat keparahannya (6). Biopsi ginjal non fokal merupakan satu-satunya metode pada penggunaan klinik terbaru untuk evaluasi fibrosis intrarenal. Namun biopsi ginjal non fokal memiliki kerugian signifikan yaitu pemeriksaan invasif dengan resiko mengalami komplikasi, pemeriksaan yang mahal, kesalahan pengambilan sampel, karena inti biopsi terdiri dari bagian kecil pada parenkim ginjal, fibrosis ginjal yang terjadi sering memiliki jaringan glomerular yang kurang pada sampel biopsi untuk memberikan diagnosis histopatologi yang akurat (6).

Pada beberapa dekade terakhir, evaluasi gangguan ginjal telah dilakukan dengan berbagai metode pemeriksaan termasuk ultrasonografi, computed tomography, magneting resonance imaging dan analisis biokimia (5). Meskipun progresivitas penyakit ginjal kronik dapat dinilai dengan pemeriksaan biokimia rutin, seperti proteinuria dan level kreatinin serum (5). Salah satu teknik imaging yang paling populer dan non invasif untuk mengevaluasi penyakit ginjal kronik adalah dengan ultrasonografi ginjal yang biasa dilakukan yaitu dengan pengukuran panjang ginjal, ketebalan kortex dan echogenitas kortex. Meskipun panjang ginjal dan ketebalan kortex berkorelasi secara signifikan dengan eGFR, namun parameter ini menunjukkan perubahan pada stadium lanjut yang membutuhkan penatalaksanaan yang sangat agresif ketika dideteksi. Oleh karena itu, dibutuhkan modalitas imaging klinis non invasif yang mampu mendeteksi penyakit ginjal pada stadium awal $(5,8)$.

Pemeriksaan shear wave elastography (SWE) merupakan teknik pemeriksaan imaging yang baru berkembang, noninvasif, murah, aman dan nyaman untuk menilai tingkat keparahan dari perubahan morfologi kronik dan untuk menentukan kategori tingkat keparahan penyakit ginjal kronik berdasarkan pengukuran elastisitas kortex $(9,10)$. Pemeriksaan ini diintegrasikan dengan mesin ultrasound konvensional dan menunjukkan pengukuran secara numerik pada elastisitas parenkim jaringan dengan pengukuran shear wave velocity (SWV) (10). Elastisitas parenkim kortex ginjal yang rendah dikaitkan dengan glomerulosklerosis, sklerosis vaskuler, fibrosis tubulointerstitial yang terjadi pada penyakit ginjal kronik stadium yang semakin berat. Pengurangan progresif SWV yang terkait dengan peningkatan stadium PGK dan dengan penurunan eGFR, hal ini dapat dijelaskan karena berkurangnya aliran darah ginjal akibat nefroangiosclerosis yang akan mempengaruhi SWV terutama pada jaringan fibrosis $(8,10)$. Penelitian tentang pemeriksaan SWE dibandingkan dengan hasil estimated glomerular filtration rate (eGFR) masih sangat terbatas.

Berdasarkan uraian tersebut diatas, maka penulis merasa tertarik untuk melalukan penelitian tentang hubungan shear wave elastography (SWE) ginjal dengan eGFR. Penelitian semacam ini belum penah dilakukan di Makassar dan di Indonesia.

Hipotesis penelitian adalah terdapat hubungan SWV ginjal dengan eGFR bahwa semakin tinggi nilai SWV maka semakin tinggi eGFR (semakin rendah stadium penyakit ginjal kronik). Tujuan penelitian ini adalah untuk mengetahui hubungan SWE ginjal dengan eGFR. Setelah mengetahui hubungan antara SWE dan eGFR maka SWE dapat direkomendasikan sebagai pemeriksaan yang noninvasif, murah, aman dan nyaman pada pasien PGK untuk melengkapi pemeriksaan ultrasonografi konvensional sehingga deteksi dini stadium awal pada penyakit ginjal kronik dapat dilakukan sehingga morbiditas pada PGK stadium lanjut (End Stage Renal Disease) dapat dicegah

\section{METODE}

\section{Desain Penelitian}

Penelitian ini adalah penelitian observasional dengan metode rancangan potong lintang cross sectional study yang dilakukan di Bagian Radiologi Rumah Sakit Umum Pusat Dr. Wahidin Sudirohusodo Makassar dari bulan September 2018 sampai Februari 2019. Variabel penelitian terdiri atas: variabel bebas SWV dalam satuan meter per second) dan variabel tergantung (eGFR dalam satuan $\mathrm{mL} /$ menit $/ 1,73 \mathrm{~m}^{2}$ ). Populasi penelitian ini adalah populasi normal (pasien dan masyarakat dengan hasil kreatinin normal yang melakukan pemeriksaan ultrasonografi ke bagian instalasi radiologi RSUP Dr. Wahidin Sudirohusodo) dan semua pasien penyakit ginjal kronik yang dirujuk dari bagian instalasi rawat jalan maupun rawat inap untuk melakukan pemeriksaan ultrasonografi abdomen ke bagian instalasi radiologi RSUP Dr. Wahidin Sudirohusodo. Sampel adalah semua populasi terjangkau yang memenuhi kriteria penelitian. 


\section{Metode Pengumpulan Data}

Penelitian ini telah mendapat persetujuan etik dari Komite Etik Penelitian Kesehatan RSUP Dr. Wahidin Sudirohusodo Makassar, RSPTN Universitas Hasanuddin, Fakultas Kedokteran Universitas Hasanuddin dengan Nomor: 974/H4.8.4.5.31/PP36-KOMETIK/2019.

Peneliti melakukan pendataan identitas penderita yang memenuhi kriteria inklusi kemudian memberikan penjelasan lengkap dan bila pasien setuju, pasien akan mengisi dan menandatangani informed consent. Peneliti menentukan nilai eGFR berdasarkan formula Modification of Diet in Renal Disease (MDRD) dalam satuan $\mathrm{ml} / \mathrm{menit} / 1,73 \mathrm{~m}^{2}$. Selanjutnya pasien menjalani pemeriksaan USG ginjal dengan menggunakan transduser konveks frekuensi 2-5 $\mathrm{MHz}$ dengan posisi supine atau lateral decubitus, namun jika kontur ginjal terhalang udara saluran cerna, maka dilakukan scan longitudinal mengikuti akses ginjal. USG ginjal dilakukan dengan metode SWE dan menentukan nilai SWV masing-masing ginjal dengan melakukan tiga kali pengukuran dan ditentukan nilai mediannya. Hasil penelitian dicatat dalam lembaran format penelitian kemudian dilakukan analisis data dan hasilnya disajikan dalam bentuk tabel dan grafik.

\section{Teknik Analisis Data}

Semua data yang diperoleh dicatat dalam formulir data penelitian, kemudian dikelompokkan berdasarkan tujuan dan jenis data, selanjutnya data akan diolah menurut metode statistik Spearman. Pengolahan data statistik berdasarkan uji korelasi menggunakan software software Statistical Programme Social Science (SPSS versi 23).

\section{HASIL}

Selama periode penelitian didapatkan jumlah sampel sebanyak 118 pasien yang terdiri dari 47 sampel normal(pasien dan masyarakat dengan kreatinin normal) dan 71 pasien penyakit ginjal kronik. Pada Gambar 1 menunjukkan contoh pemeriksaan shear wave elastography pada salah satu ginjal pasien PGK, tanda panah menunjukkan regio of Interest (ROI) yang dilakukan pada tiga lokasi kortex ginjal, maisng-masing nilai SWV tampil pada monitor USG, nilai median diantara tiga nilai SWV tersebut yang diambil yang kemudian dihubungkan dengan eGFR pasien dalam pengelolaan data.

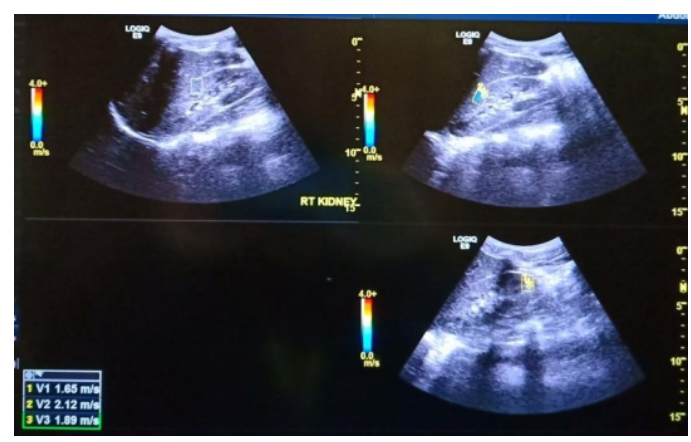

Gambar 1. Contoh hasil pemeriksaan shear wave elastography ginjal untuk mengukur shear wave velocity ginjal
Jumlah sampel normal terbanyak berjenis kelamin perempuan dan dengan rentang usia terbanyak adalah 2030 tahun. Sedangkan pada sampel penyakit ginjal kronik (PGK), sampel terbanyak berjenis kelamin laki-laki, dengan rentang usia terbanyak antara 61-70 tahun. Ada hubungan bermakna antara jenis kelamin dengan kejadian PGK dengan nilai $p$ sebesar 0,004 dimana kejadian PGK lebih sering terjadi pada laki-laki dibandingkan perempuan. Terdapat pula hubungan yang bermakna antara umur dengan kejadian PGK dengan nilai $p<0,001$ dimana usia tua (61-70 tahun) lebih sering mengalami PGK dibanding usia muda Tabel 1.

Tabel 1. Distribusi sampel berdasarkan demografi

\begin{tabular}{|c|c|c|c|c|c|}
\hline & \multicolumn{2}{|c|}{ PGK } & \multicolumn{2}{|c|}{ Normal } & \multirow{2}{*}{ Nilai $p$} \\
\hline & $\mathbf{N}$ & $\%$ & $n$ & $\%$ & \\
\hline Jumlah & 71 & & 47 & & \\
\hline Jenis Kelamin & & & & & 0,004 \\
\hline Laki-laki & 42 & 59,2 & 15 & 31,9 & \\
\hline Perempuan & 29 & 40,8 & 32 & 68,1 & \\
\hline Umur & & & & & $<0,001$ \\
\hline $20-30$ & 5 & 7,0 & 31 & 66,0 & \\
\hline $31-40$ & 6 & 8,4 & 2 & 4,2 & \\
\hline $41-50$ & 10 & 14,1 & 3 & 6,4 & \\
\hline $51-60$ & 19 & 26,8 & 5 & 10,6 & \\
\hline $61-70$ & 22 & 31,0 & 3 & 6,4 & \\
\hline $71-80$ & 9 & 12,7 & 3 & 6,4 & \\
\hline
\end{tabular}

Keterangan: $n=$ jumlah sampel, $\%=$ persentase, $p=p$ value

Pada Tabel 2 menunjukkan nilai median SWV populasi normal pada ginjal kanan antara lain $2,02 \pm 0,32 \mathrm{~m} / \mathrm{s}$ dan pada ginjal kiri $2,01 \pm 0,32 \mathrm{~m} / \mathrm{s}$ yang cenderung menurun dengan bertambahnya usia. Pada rentang umur 20-30 tahun nilai SWV ginjal kanan dan kiri sebesar $2,1 \pm 0,24 \mathrm{~m} / \mathrm{s}$ dan $2,0 \pm 0,27 \mathrm{~m} / \mathrm{s}$ sedangkan pada rentang umur $71-80$ tahun sebesar $1,38 \pm 0,32 \mathrm{~m} / \mathrm{s}$ dan $1,40 \pm 0,50 \mathrm{~m} / \mathrm{s}$.

Tabel 2. Nilai median shear wave velocity ginjal kanan dan kiri berdasarkan kategori umur pada populasi normal

\begin{tabular}{ccc} 
Rentang Usia (tahun) & SWV Ginjal kanan(m/s) & sWV Ginjal kiri(m/s) \\
\hline $20-30$ & $2,1 \pm 0,24$ & $2,0 \pm 0,27$ \\
$31-40$ & $2,1 \pm 0,16$ & $2,0 \pm 0,67$ \\
$41-50$ & $1,64 \pm 0,30$ & $1,64 \pm 0,27$ \\
$51-60$ & $1,68 \pm 0,30$ & $1,76 \pm 0,18$ \\
$61-70$ & $1,65 \pm 0,70$ & $1,59 \pm 0,17$ \\
$71-80$ & $1,38 \pm 0,32$ & $1,40 \pm 0,50$ \\
\hline
\end{tabular}

Keterangan: Uji Korelasi Spearman, $\mathrm{SWV}=$ shear wave velocity

Pada Tabel 3 dengan hasil uji korelasi Spearman menunjukkan terdapat korelasi yang signifikan antara SWV ginjal dengan eGFR dengan nilai $p<0,0001$ dengan kekuatan korelasi kuat dengan nilai $r=0,798$ pada ginjal kanan dan nilai $r=0,765$ pada ginjal kiri dengan arah korelasi positif. Semakin rendah nilai SWV ginjal maka semakin rendah pula eGFR (semakin tinggi stadium penyakit ginjal kronik). 
Tabel 3. Hubungan antara shear wave velocity ginjal kanan dan ginjal kiri dengan eGFR MDRD

\begin{tabular}{cccl}
\hline & \multicolumn{3}{c}{ eGFR MDRD } \\
\hline Nilai & $\mathbf{R}$ & $\mathbf{p}$ & $\mathbf{n}$ \\
Shear wave velocity kanan & 0,798 & 0,003 & 71 \\
Shear wave velocity kiri & 0,765 & 0,012 & 71 \\
\hline
\end{tabular}

Keterangan: Data primer; $n=$ jumlah sampel; $r=$ koefisien korelasi $; p=$ $\mathrm{p}$ value

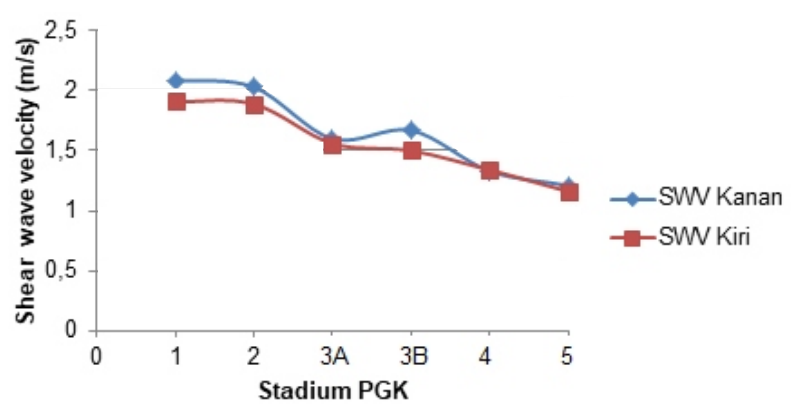

Grafik 1. Grafik nilai shear wave velocity (SWV) ginjal kanan dan kiri berdasarkan stadium PGK

Grafik 1 menunjukkan terdapat kecenderungan bahwa semakin rendah nilai SWV ginjal maka semakin rendah pula eGFR (semakin tinggi stadium penyakit ginjal kronik).

Pada Tabel 4, juga didapatkan korelasi antara tekanan darah dan eGFR dengan nilai $p=0,003$, dengan kekuatan korelasi lemah $(r=-0,346)$, dengan arah korelasi negatif, bahwa semakin tinggi tekanan darah maka semakin rendah eGFR (semakin tinggi stadium PGK). Demikian pula didapatkan korelasi antara tekanan darah dan shear wave velocity ginjal kanan dan kiri dengan nilai $\mathrm{p}=0,012$ dan $p=0,004$, dengan kekuatan korelasi lemah $(r=-0,298)$ pada ginjal kanan dan $(r=-0,336)$ pada ginjal kiri, bahwa semakin tinggi tekanan darah maka nilai shear wave velocity ginjal semakin rendah.

Tabel 4. Korelasi antara tekanan darah, estimated glomerular filtration rate dan shear wave velocity ginjal kanan dan kiri

\begin{tabular}{lccl}
\hline & \multicolumn{3}{c}{ Tekanan Darah } \\
\hline \multicolumn{1}{c}{ Nilai } & $\mathbf{r}$ & $\mathbf{p}$ & $\mathbf{n}$ \\
eGFR MDRD & $-0,346$ & 0,003 & 71 \\
Shear wave velocity kanan & $-0,298$ & 0,012 & 71 \\
Shear wave velocity kiri & $-0,336$ & 0,004 & 71 \\
\hline
\end{tabular}

Keterangan: Data primer; $\mathrm{n}=$ jumlah sampel; $\mathrm{r}=$ koefisien korelasi $; \mathrm{p}=\mathrm{p}$ value; eGFR=estimated glomerular filtration rate; $M D R D=$ Modification of Diet in Renal Disease

Pada Tabel 5 menunjukkan korelasi antara proteinuria dan eGFR dengan nilai $\mathrm{p}(<0,0001)$ dengan kekuatan korelasi sedang $(r=-0,520)$ dengan arah korelasi negatif. Semakin tinggi proteinuria maka semakin rendah eGFR (semakin tinggi stadium PGK). Terdapat korelasi antara proteinuria dan shear wave velocity ginjal kanan dan kiri dengan nilai $p(<0,0001)$ dengan kekuatan korelasi sedang $(r=-0,404$ dan $-0,488)$. Semakin tinggi proteinuria maka semakin rendah shear wave velocity ginjal kanan dan kiri.
Tabel 5. Korelasi antara proteinuria, eGFR dan shear wave velocity ginjal kanan dan kiri

\begin{tabular}{lccl}
\hline & \multicolumn{3}{c}{ Proteinuria } \\
\hline Nilai & $\mathbf{r}$ & $\mathbf{p}$ & $\mathbf{n}$ \\
eGFR MDRD & $-0,520$ & $<0,0001$ & 71 \\
Shear wave velocity kanan & $-0,404$ & $<0,0001$ & 71 \\
Shear wave velocity kiri & $-0,488$ & $<0,0001$ & 71 \\
\hline
\end{tabular}

Keterangan: Data primer; $n=$ jumlah sampel; $r=$ koefisien korelasi $; p=p$ value

\section{DISKUSI}

Pada penelitian ini diperoleh nilai median shear wave velocity pada populasi normal, yaitu pada ginjal kanan sebesar $2,02 \pm 0,32 \mathrm{~m} / \mathrm{s}$ dan pada ginjal kiri $2,01 \pm 0,32 \mathrm{~m} / \mathrm{s}$ yang cenderung menurun dengan bertambahnya usia. Didapatkan pula adanya korelasi positif yang signifikan antara SWV ginjal kanan maupun ginjal kiri dengan eGFR dengan nilai $\mathrm{p}(<0,05)$ dengan kekuatan korelasi kuat, bahwa semakin rendah nilai SWV baik pada ginjal kanan maupun ginjal kiri, maka semakin rendah eGFR (semakin tinggi stadium PGK). Pada penelitian ini juga didapatkan korelasi negatif antara proteinuria dan eGFR serta SWV ginjal kanan maupun kiri, bahwa semakin tinggi stadium proteinuria maka semakin rendah eGFR (semakin tinggi stadium PGK). Didapatkan pula korelasi antara tekanan darah dan eGFR maupun dengan SWV ginjal kanan dan kiri dengan nilai $p(<0,05)$ dengan kekuatan korelasi lemah $(r=-$ $0,346,-0,298, r=-0,336)$, bahwa semakin tinggi tekanan darah maka semakin rendah eGFR (semakin tinggi stadium PGK) demikian pula degan nilai SWV ginjal.

Pada sampel populasi normal sebanyak 47 orang, didapatkan nilai median SWV pada ginjal kanan sebesar $2,02 \pm 0,32 \mathrm{~m} / \mathrm{s}$ dan pada ginjal kiri $2,01 \pm 0,32 \mathrm{~m} / \mathrm{s}$ yang cenderung menurun dengan bertambahnya usia. Adapun dalam textbook Elastography oleh Barr, nilai SWV normal adalah 2,24-2,37m/s dengan standar deviasi $0,7 \mathrm{~m} / \mathrm{s}$ (11). Bob dkk dalam penelitiannya memperoleh nilai SWV sebesar $2,58 \pm 0,78 \mathrm{~m} / \mathrm{s}$ pada ginjal kanan dan $2,46 \pm 0,81 \mathrm{~m} / \mathrm{s}$ pada ginjal kiri (12). Adapun nilai SWV ginjal pada pasien normal pada penelitian yang dilakukan oleh Goya dkk adalah 2,35 $\pm 0,39 \mathrm{~m} / \mathrm{s}$ (13). Perbedaan nilai normal ini dikaitkan dengan perbedaan jumlah sampel dan sebaran umur sampel normal serta perbedaan jenis modalitas USG yang digunakan. Terdapat penurunan nilai SWV baik pada ginjal kanan maupun kiri seiring dengan pertambahan umur. Hal ini terkait dengan perubahan usia yang merupakan faktor yang berkaitan dengan gangguan fungsi dan struktur ginjal (kidney aging), baik itu dari segi berat, perubahan nefron maupun fungsi ginjal meskipun tidak ada penyakit khusus yang berkaitan dengan ginjal, pada usia tua perubahan fungsi ginjal dikaitkan dengan berkurangnya total body water, penurunan aliran darah ke ginjal, penurunan kemampuan konsentrasi urin, peningkatan sekresi antidiuretik hormon, peningkatan atrial natrium peptida, penurunan sekresi aldosteron, penurunan respon haus, dan penurunan klirens air. Hal tersebut merupakan akibat fenomena proses penuaan (aging) (10).

Pada penelitian dengan SWE ini, didapatkan adanya korelasi positif antara SWV ginjal kanan maupun ginjal kiri dengan eGFR dengan nilai $p(<0,05)$ dengan kekuatan korelasi kuat, bahwa semakin tinggi nilai SWV baik pada ginjal kanan maupun ginjal kiri, maka semakin tinggi eGFR 
(semakin rendah stadium PGK). Hasil penelitian ini sama dengan yang didapatkan dari penelitian Bob et al., yang meneliti 104 pasien dengan dan tanpa PGK, didapatkan bahwa nilai SWV menurun dengan menurunnya eGFR (12). Demikian pula pada penelitian Goya et al., yang meneliti 281 orang sehat dan 114 pasien nefropati diabetik didapatkan semakin rendah SWV maka semakin tinggi stadium PGK $(13,14)$. Pada penelitian Asano et al., yang meneliti 14 orang sehat dan 319 pasien PGK, juga didapatkan bahwa SWV menurun secara bersamaan dengan penurunan eGFR (15). Asano et al., melaporkan bahwa terdapat pengurangan progresif SWV yang terkait dengan peningkatan stadium PGK dan dengan penurunan eGFR, hal ini dapat dijelaskan karena berkurangnya aliran darah ginjal akibat nefroangiosklerosis yang akan mempengaruhi SWV terutama pada jaringan fibrosis (8).

Terdapat korelasi antara tekanan darah dan eGFR maupun dengan SWV ginjal kanan dan kiri dengan nilai $p(<0,05)$ dengan kekuatan korelasi lemah $(r=-0,346,-0,298, r=-$ 0,336 ), bahwa semakin tinggi tekanan darah maka semakin rendah eGFR (semakin tinggi stadium PGK) demikian pula degan nilai SWV ginjal. Hal ini sesuai dengan penelitian Okin et al., bahwa meningkatnya level tekanan darah sistolik dikaitkan dengan peningkatan risiko penyakit ginjal tahap akhir atau dengan meningkatkan resiko progresivitas dan berlanjutnya perkembangan penyakit ginjal kronik atau perburukan eGFR. Hipertensi dapat menjadi penyebab maupun menjadi akibat dari penyakit ginjal kronik. Patogenesis yang menentukan kerusakan ginjal akibat hipertensi secara umum dibagi menjadi 3 kategori yaitu (a) beban tekanan darah sistemik; (b) derajat beban tekanan darah sistemik tersebut diteruskan ke vascular bed ginjal; (c) kerentanan jaringan lokal pada derajat barotrauma yang diberikan (16). Adapun faktor yang menyebabkan hipertensi pada penyakit ginjal kronik antara lain gangguan ekskresi sodium yang menyebabkan penambahan volume cairan extraseluler, aktivasi sistem renin-angiotensin antigen yang mengakibatkan vasokonstriksi langsung akibat aktivasi simpatis, gangguan keseimbangan prostaglandin maupun kinin yang mengakibatkan vasokonstriksi, faktor endotelin yang menyebabkan cedera pada ginjal dan berkurangnya nitrit oxida yang

\section{DAFTAR PUSTAKA}

1. Atkin RC. The Epidemiology of Chronic Kidney Disease. Kidney International. 2005; 67(94): 14-18.

2. Haileamlak A. Chronic Kidney Disease is on the Rise. Ethiopian Journal of Health Science. 2018; 28(6): 681-682.

3. Hill NR, Fatoba ST, Oke JL, et al. Global Prevalence of Chronic Kidney Disease-A Systematic Review and Meta-Analysis. PLoS One. 2016; 11(7): 1-18.

4. Prodjosudjadi W and Suhardjono A. End-Stage Renal Disease in Indonesia: Treatment Development. Ethnicity \& Disease. 2009; 19(1): 33-36.

5. Hassan K, Loberant N, Abbas N, Fadi H, Shadia H, and Khazim K. Shear Wave Elastography Imaging for Assessing the Chronic Pathologic Changes in Advanced Diabetic Kidney Disease. Therapeutics and Clinical Risk Management. 2016; 12: 1615-1622.

6. Samir AE, Allegretti AS, Zhu Q, et al. Shear Wave menyebabkan berkurangnya efek vasodilator (17).

Semakin tinggi stadium proteinuria maka semakin rendah eGFR (semakin tinggi stadium PGK). Hal ini sama dengan hasil penelitian Lin et al., menemukan adanya korelasi antara elastisitas ginjal dengan proteinuria dengan nilai $\mathrm{p}<0,001$ menggunakan Real Time Elastography (8). Demikian pula dengan hasil penelitian Goya et al., yang menemukan korelasi signifikan antara SWV dengan proteinuria dengan nilai $p<0,01$ (13). Proteinuria berkaitan erat dengan risiko progresivitas penyakit ginjal kronik baik pada pasien non diabetik maupun pada pasien diabetik terkait dengan penurunan eGFR dan kecenderungan menjadi penyakit ginjal tahap akhir. Proteinuria kronik terjadi pada hilangnya selektivitas barrier glomerular untuk memfiltrasi protein. Pada penelitian pengurangan massa ginjal dengan nefrektomi pada $5 / 6$ ginjal, maka sisa glomerulus akan mengalami hipertrofi dan tonus arteriole aferen dikeluarkan oleh derajat yang lebih besar dibandingkan dengan arteriole aferen sendiri. Perubahan ini, awalnya akan membantu untuk mengurangi akibat fungsional dari kehilangan nefron, yaitu kerusakan akhir, yang menyebabkan cedera berat pada nefron intak yang tersisa. Peningkatan tekanan kapiler intraglomeruler dan tekanan perfusi akan menyebabkan peregangan kapiler glomerulus, kemudian mengakibatkan gangguan fungsi filtrasi dan kehilangan molekul besar seperti protein dalam urin (proteinuria) (18).

Dapat disimpulkan bahwa nilai median shear wave velocity pada kelompok sampel normal adalah $2,02 \pm 0,32 \mathrm{~m} / \mathrm{s}$ pada ginjal kanan $2,01 \pm 0,32 \mathrm{~m} / \mathrm{s}$ pada ginjal kiri yang cenderung menurun dengan bertambahnya usia. Terdapat korelasi positif yang signifikan antara nilai SWV pada ginjal kanan dan kiri dengan eGFR. Pada penelitian ini, terdapat pula korelasi negatif yang signifikan antara tekanan darah dan proteinuria dengan eGFR maupun dengan SWV pada pasien penyakit ginjal kronik. Pengukuran nilai SWV dengan SWE dapat direkomendasikan sebagai salah satu metode untuk menilai progresifitas stadium penyakit ginjal kronik dan menjadi metode imaging non invasif yang mampu mendeteksi stadium awal penyakit ginjal kronik.
Elastography in Chronic Kidney Disease: A Pilot Experience in Native Kidneys. BioMed Central Nephrol. 2015; 16(119): 1-9.

7. Belguith $\mathrm{H}$. Use of e-GFR formula to Evaluate kidney Function in Diabetes Mellitus Patients in Al-Jouf area, Saudi Arabia. Journal of Biomedical Science. 2012; 1(2): 1-9.

8. Lin HY, Lee YL, Lin KD, et al. Association of Renal Elasticity and Renal Function Progression in Patients with Chronic Kidney Disease Evaluated by Real-Time Ultrasound Elastography. Scientific Reports. 2017; 7: 1-8.

9. Bruno C, Brugnara M, Micciolo R, et al. Renal Shear Wave Velocity and Estimated Glomerular Filtration Rate in Children with Chronic Kidney Disease. Saudi Journal of Kidney Diseases and Transplantation. 2016; 27(6): 1139-1147.

10. Guo LH, Xu HX, Fu HJ, Peng A, Zhang YF, and Liu LN. Acoustic Radiation Force Impulse Imaging for 
Noninvasive Evaluation of Renal Parenchyma Elasticity: Preliminary Findings. PLoS ONE. 2013; 8(7): 1-8.

11. Barr RG. Elastography, A Practical Approach. 1st edition. New York: Thieme Medical Publishers; 2017; hal. 120-126.

12. Bob F, Grosu J, Sporea I, et al. Ultrasound-Based Shear Wave Elastography in the Assessment of Patients with Diabetic Kidney Disease. Ultrasound in Medicine \& Biology. 2017; 43(10): 2159-2166.

13. Goya C, Kilinc F, Hamidi C, et al. Acoustic Radiation Force Impulse Imaging for Evaluation of Renal Parenchyma Elasticity in Diabetic Nephropathy. American Journal of Roentgenology. 2015; 204(2): 324-329.

14. Metrovic T. What is Nephropathy? (Internet) 2018. https://www.news-medical.net/health/What-is-
Nephropathy.aspx [diakses tanggal 2019 Jan 22].

15. Asano K, Ogata A, Tanaka K, et al. Acoustic Radiation Force Impulse Elastography of the Kidneys: Is Shear Wave Velocity Affected by Tissue Fibrosis or Renal Blood Flow? Journal of Ultrasound in Medicine. 2014; 33(5): 793-801.

16. Bidani AK and Griffin KA. Pathophysiology of Hypertensive Renal Damage: Implications for Therapy. Hypertension. 2004; 44(5): 595-601.

17. Tedla FM, Brar A, Browne R, and Brown C. Hypertension in Chronic Kidney Disease: Navigating the Evidence. International Journal of Hypertension. 2011;2011: 1-9.

18. Cravedi and Remuzzi G. Pathophysiology of Proteinuria and Its Value as an Outcome Measure in Chronic Kidney Disease. British Journal of Clinical Pharmacology. 2013; 76(4): 516-523 